\title{
An evaluation of agroforestry on a Bay of Plenty hill country farm
}

\author{
R.L. KNOWLES', G.M. BRANN ${ }^{2}$ and G.J. BRANN ${ }^{2}$ \\ 'Forest Research Institute, Private Bag 3020, Rotorua
}

${ }^{2}$ Roydon Downs,-R.D. 9, Te Puke

\section{A b s t r a c t}

Between 1970 and 1991, 53 ha of Pinus radiata plantations were established and managed in an agroforestry system on a 245 ha farm at Roydon Downs in the eastern Bay of Plenty. Plantations on a further 30 haareplanned. This paperoutlines the experience gained, and uses recently developed agroforestry modelling systems to evaluate the current and projected physical yields, cash flow and profitability of several agroforestry options when applied to a typical Bay of Plenty sheep and beef farm, The increasing availability of genetically improved tree stocks, together with developments in silvicultural techniques, have resulted in a low cost, easily managed tree crop, using mainly family labour. The objective is to produce high quality domestic or export sawlogs and peeler logs. Planting the least productive third of the farm is predicted to more than double the total farm surplus. For farming to provide an equivalent economic return from the same land, gross margins would have to increase from $\$ 29$ to $\$ 60 /$ livestock unit (LSU). or livestock carrying capacity would have to increase from 8 to $16 \mathrm{LSU} / \mathrm{ha}$. Options involving 135 stems/ha and 225 stems/ha gave a similar economic return. However, concerns about the quality of the final product indicate that cash flow constraints should be met by varying the size and rate of planting, rather than by reducing final crop stocking. A method of financing initial costs based on sharing final revenues with investors is presented.

Keywords agroforestry, Pinus radiata, estate model, profitability

\section{Introduction}

A model Bay of Plenty sheep and beef farm, as describedin the MAF Farm Monitoring Reports, covers 275 ha and grazes 2940 livestock units (Ministry of Agriculture and Fisheries 1990). The Roydon Downs farm, $10 \mathrm{~km}$ south-east of Paengaroa and with a gross area of 245 ha and total livestock units of 2900, is very similar to the MAF model Bay of Plenty sheep and beef farm. The farm livestock carrying capacity averages $11.8 \mathrm{LSU} / \mathrm{ha}$, but varies from around $8 \mathrm{LSU} /$ ha on $60 \%$ of the property, which is made up of short but steep hills, to around 17 LSU/ha on the $40 \%$ which is in broad valley bottoms or ridge crests. These latter areas support highly productive ryegrass and white clover pastures, while the hill faces are predominantly in lowerproducing species, such as browntop (Agrostis tenuis), summer grass (Digitaria sanguinalis), Poa spp.. Paspalum spp., sweet vernal (Anthoxanthum odoratum), ratstail (Sporobolus africanus) and rice grass (Microlaena stipoides). We consider the longterm agricultural potential of this hill land to be low, both physically and economically.

The Paengaroa hill soils, which are derived from Kaharoa ash overlaying Taupo ash, are readily eroded if exposed by livestock or cultivation on the steeper faces. For one-third of the property in steep faces, agroforestry has been actively investigated as a landuse opportunity. The Bay of Plenty produces excellent tree growth rates, the forestry infrastructure is already in place with much of the information concerning tree management readily available, and an increasingly active and competitive log market is developing.

Planting started in 1970, and has averaged 2.6 ha per year. To date, 53 ha of radiata pine have been established, with a further 30 ha planned (Figure 1). Another 15 ha of a range of other species have been planted, the most successful being Cupressus lusitanica, Eucalyptus saligna, E. bottyoides. and Acacia melanoxylon. The pine plantations have been established and tended with mostly family labour. Initially a conservative regime was followed with relatively high initial and final crop stockings per hectare, but as knowledge from agroforestry research and improved genetic material have become available, initial and final tree stockings have beenreduced, with commensurate reductions in labour requirements and relative increases in undcrstorey livestock carrying capacity (Brann \& Brann 1988). A hectare of the current regime, which involves planting 150 stems/ha and pruning about $135 \mathrm{stems} / \mathrm{ha}$ to $6 \mathrm{~m}$, requires on 
average 32 hours of work spread over the first 7 years, withdirect costs of seedlings and herbicide amounting to just $\$ 85 / \mathrm{ha}$. Sheep are grazed among the trees within 18 months of planting, and older cattle within 5 years. Some care is taken to avoid browsing and debarking damage, butessentiallylivestockarerotationallygrazed as in unplanted paddocks. A small 0.6 ha plantation aged 26 years was felled in 1990 , netting $\$ 20,600$ (Brann 1991). The main felling is expected to start in 3 years and, after a lead-in of 7 years, average 3 ha per year on a 26- to 27-year rotation. The short hill slopes are suitable for logging by crawler tractor, and the property is located less than $50 \mathrm{~km}$ from Mt Maunganui wharf. This experience on the Roydon Downs property has been used as the basis on which to evaluate some land-use options involving pine agroforestry.

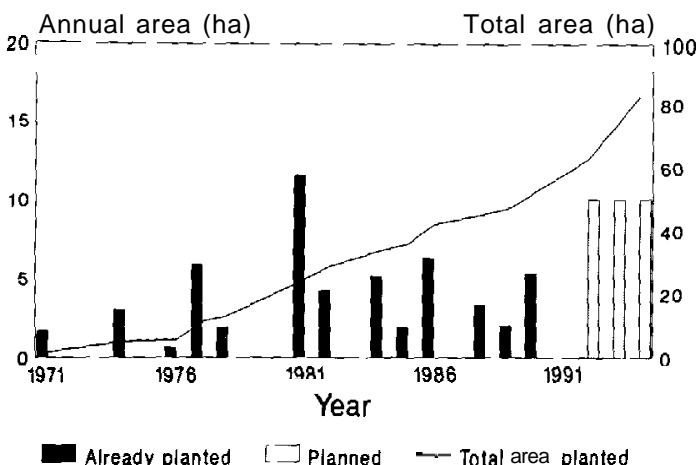

Figure 1 Actual and planned plantings.

\section{Methods}

To evaluate agroforestry for the typical Bay of Plenty beef and sheep farm which has not yet diversified into agroforestry, it was assumed that an identical planting pattern would be followed, but with planting starting in 1991. The base farm productivity was taken from the MAF Farm Monitoring Report for the Bay of Plenty Hill Country Sheep and Beef Farm, Class 4 (Ministry of Agriculture\&Fisheries 1990). Experience on the Roydon Downs property was used as the basis to determine tree growth rates, labour requirements and for estimating roading and logging costs. Revenue from the sale of standing trees was based on current prices being offered for pruned logs, adjusted by $\$ 0.35$ for each millimetre change in clearwood sheath from a base of $150 \mathrm{~mm}$. Current prices for unpruned export logs were used with a maximum branch size of $10 \mathrm{~cm}$ set for Japanese 'A' grade, and $15 \mathrm{~cm}$ for Korean ' $\mathbf{K}$ ' grade. Allowance was made for sale commission, log transport, logging (including supervision) androading.

The projections for livestock carrying capacity used in this study are based on analysis of the Tikitere agroforestry trial, located $20 \mathrm{~km}$ from the farm (Percival \& Knowles 1988). and include an allowance for the slightly poorer livestock performance which occurs when sheep are continually grazed on understorey pasture (Percival et al. 1988).

An integrated computer-based modelling system, PC-STANDPAK, was used to derive yields in the above $\log$ grades for rotation ages of 22-32 years. These yield tables, together with the farm details, were thenentered into a recently developed agroforestry estate model which simulated the consequences of various felling patterns on annual wood flows, costs and revenues, residual livestock numbers and labour requirements (see Appendix 1 for details of the basic assumptions).

The current regime (135 stems/ha final crop on 83 ha) was then compared to a final crop of $225 \mathrm{stems} / \mathrm{ha}$, also on 83 ha. A third option comparing 225 stems/ha on a reduced area ( 70 ha of agroforestry and 13 ha of open pasture), was also evaluated, with all agroforestry options compared with conventional farming with no trees. These regimes are referred to as ' 135 ', ' 225 ', '225/70' and 'farming' respectively.

\section{Results}

\section{Current situation}

Farm costs and revenues, with no agroforestry, are based on the December 1990 MAF Farm Monitoring Report for Bay of Plenty Hill country (Ministry of Agriculture \& Fisheries 1990). This shows that the typical beef and sheep farm earns a surplus of $\$ 56,000$ (Figure 2). This surplus is used to pay tax $(\$ 7500)$, and service debt $(\$ 34,800)$. leaving just $\$ 13,700$ for personal drawings and new capital development. The farming gross margin (gross income less variable costs) is reported as $\$ 28.73 /$ LSU.
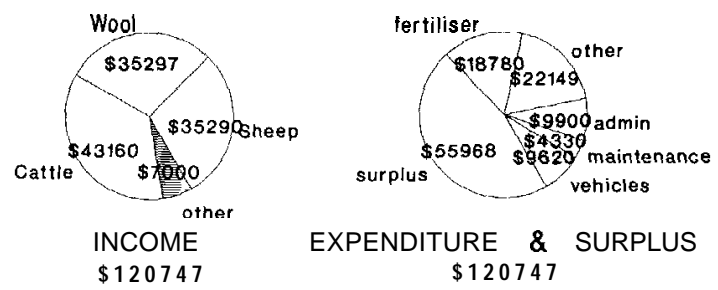

Figure 2 Farm income, expenditure and surplus in 1990/91 (no agroforestry). 


\section{The consequences of adopting agroforestry}

\section{(a) Effects on livestock numbers}

Without trees, the typical farm carries 2940 LSU. The 225 regime provides useful grazing for 10 years after planting, and the 135 regime for 15 years (Figure 3a). When calculated over the total farm, livestock carrying capacity is estimated to be eventually reduced by 450 LSU where 83 ha is managed under the 135 regime, and by 530 LSU under the 225 regime (Figure $3 \mathrm{~b}$ ). In both regimes, these reductions occur when an equal area is planted, tended and felled each year. The forestry term for this is "normality". Where 225 stems/ ha are grown on 70 ha, livestock numbers will be the same as the 135 regime on 83 ha.

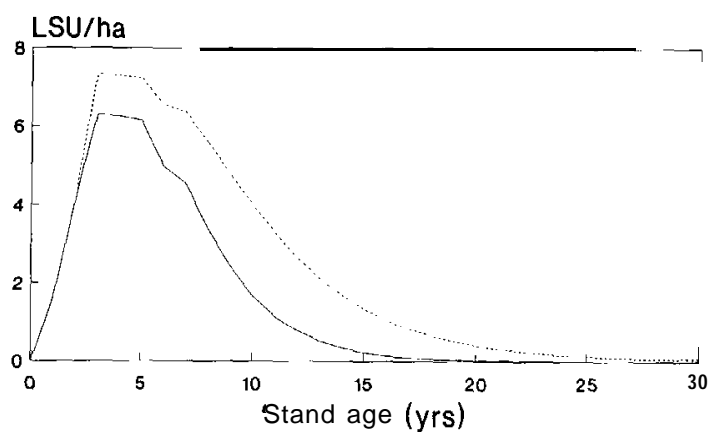

135 stems/ha 225 stems/ha

Figure 3a Livestock units on one ha of agroforestry.

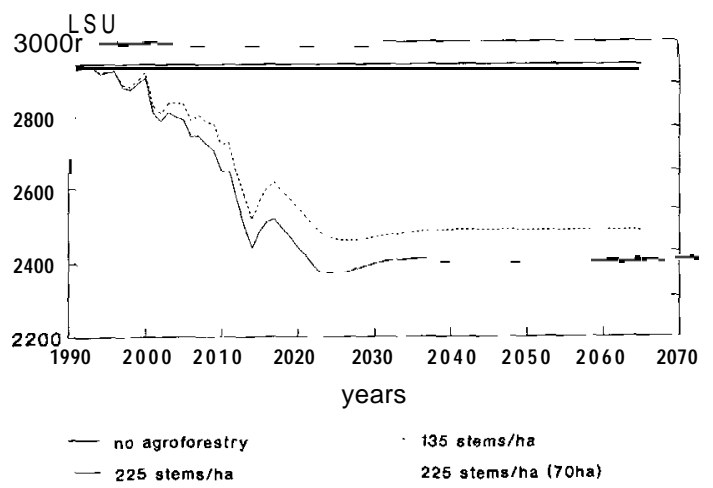

Figure 3b Livestock units carried on the farm.

\section{(b) Effects on labour requirements}

Atnormality, labour requirements of the $135 \mathrm{stems} / \mathrm{ha}$ regime are 12 days/yr, compared with 20 days/yr for the 225 regime and 17 days/yr for the $225 / 70$ regime (Figure 4).

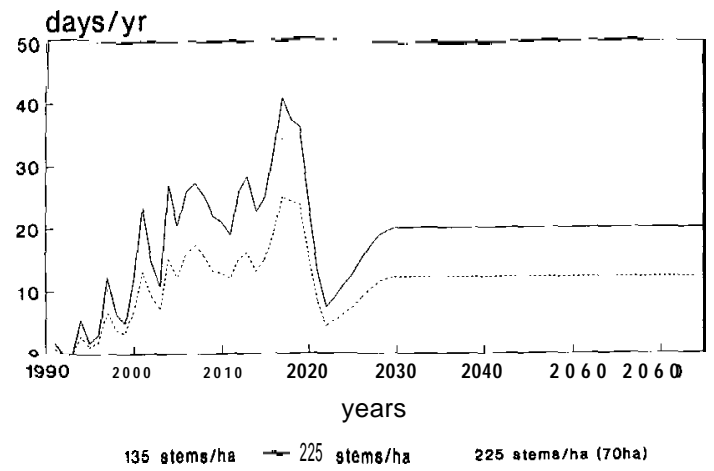

Figure 4 Labour requirement.

\section{(c) Cash flow}

The effect on the farm cash surplus was estimated for the 135 and 225 stems/ha regime on 83 ha, using either family labour for silvicultureor contract labour (costing $\$ 20 / \mathrm{hr}$ ). The 135 regime has a maximum deficit of $\$ 14,700$ in the 24 th year using contract labour, and $\$ 12,000$ using family labour. For the 225 regime, maximum deficits are $\$ 19,700$ (contract labour) and $\$ 15,100$ (family labour).

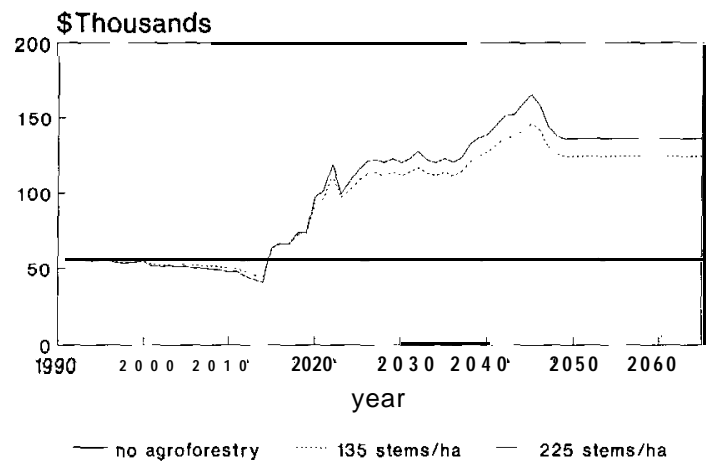

\$Thousands

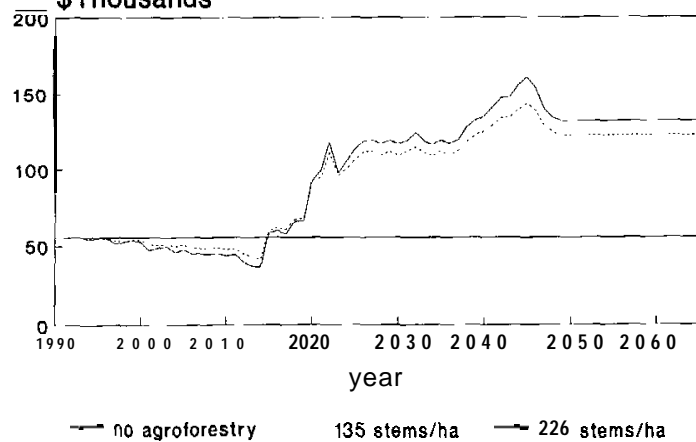

Figures 5a (family labour - above) and $\mathbf{5 b}$ (contract labour -below) Farm cash flows comparing 135 stems/ha and 225 stems on 83 ha. 
Once felling starts, the largest surplus is contributed by the 225 regime using family labour (a net gain of $\$ 80,100$ over farming) compared with a net gain of $\$ 68,500$ using 135 stems/ ha. Total farm cash flows, which include the contribution from the remaining 192 ha of open pasture, are shown in Figure 5. The 225/ 70 regime (which provides an extra 13 ha of open pasture) produced very similar cash flows to the 135 regime on 83 ha. Figure 6 shows the total farm cash flows with these two options compared, using contract labour. The farm surplus is predicted to increase at normality from $\$ 56,000$ without agroforestry to $\$ 132,000$ with agroforestry using 225 stems/ ha and contract labour (Figure 7).
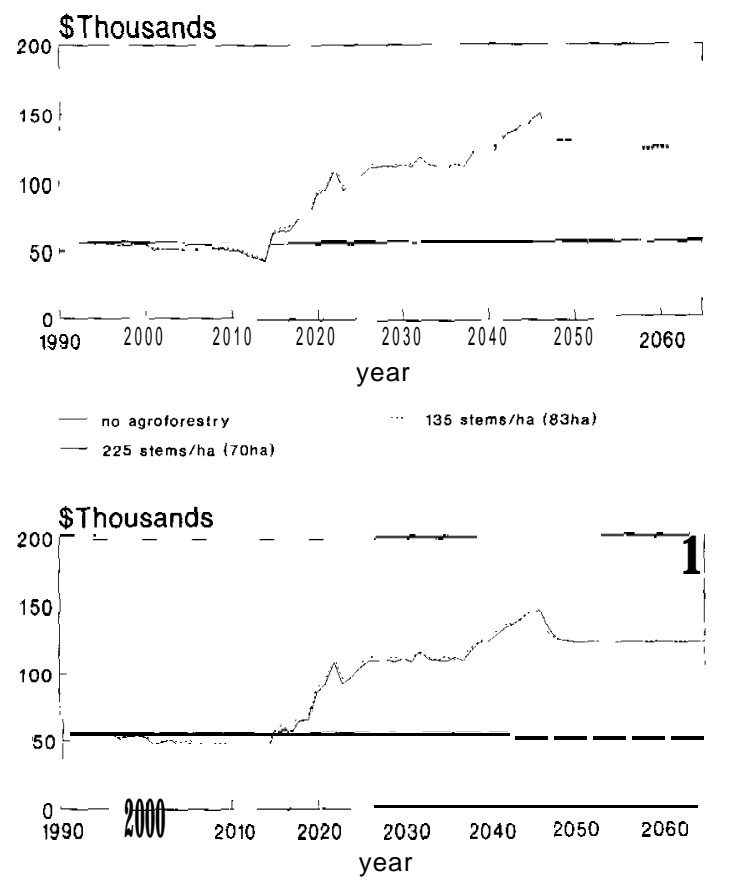

- no agrotorestry

135 stems/ha (B3ha)

225 stems/ha (70ha)

Figures 6a (family labour $\mathbf{-}$ top) and $\mathbf{6 b}$ (contract labour - above) Farm cash flows comparing 135 stems/ha on 83 ha with 225 stems/ha on 70 ha.

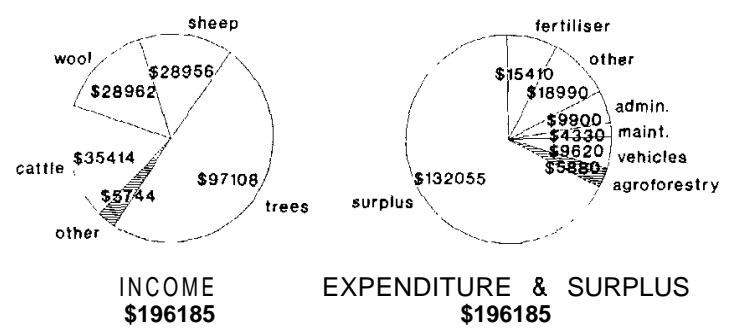

Figure 7 Farm income, expenditure and surplus, with agroforestry at 225 stems/ha using contract labour, at normality. (d) Profitability

The profitability of the various agroforestry options was compared with farming (i.e., without trees) in terms of net present value. Since fixed costs, induding land, are common to all options, the analysis wasdoneonmarginal costs and revenues. Using family labour, agroforestry for all three options was similar, with all being more profitable than farming at real pretax discountrates less than $13 \%$ (Figure 8). To illustrate the sensitivity of the results to farming gross margin, the 135 stems/ha and the $225 \mathrm{stem} /$ ha regimes were compared with farming using a wide range of farming gross margins, at a discount rate of $8 \%$. This showed that for both regimes agroforestry was more profitable than farming at gross margins of less than about \$60/LSU using family labour, and \$44.53 using contract labour. Current (June 1991) gross margins are calculated at $\$ 23.88$, indicating that there is currently a very large differential in favour of agroforestry.

An alternative option is to improve the carrying capacity of the hills under a more intensive agricultural system. Analysis of this shows that at a gross margin of $\$ 28.73 / \mathrm{LSU}$, livestock carrying capacity would have to increase from the current $8 \mathrm{LSU} / \mathrm{ha}$ to more than 16 LSU/ha before agroforestry at 225 stems/ ha using family labour was less profitable than farming. While this increase may be physically possible, to achieve it would requirerelatively expensive inputs of fertiliser, fencing, improved pasture species and labour. Increased livestock pressure (particularly from cattle) on lightpumice hill soils can increase erosion. Clearly, trees are aneconomic and environmentally appropriate crop for this land.

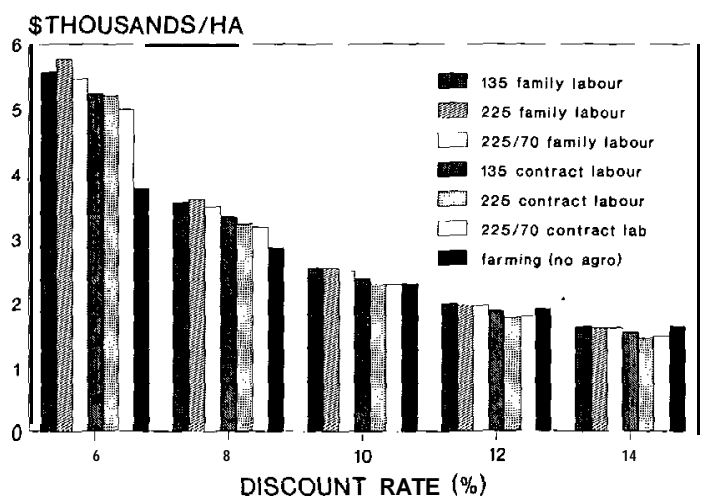

Figure $\mathbf{8}$ Net present values compared for agroforestry options, and fanning (note that fixed costs are excluded).

\section{(e) Products}

The values used for both the 135 and 225 regime assumed that the quality of the unpruned log grades 
arising from these regimes would be similar. This is because the current limits on branch size are quite large. Recent measurements of branches in unpruned logs at several agroforestry trial sites, and the computer projections using STANDPAK, have indicated a significant increase in branch size at lower tree stockings. For example, the largest branch in the zone 5.7 to $11.2 \mathrm{~m}$ above ground measured at Whatawhata was $12.8 \mathrm{~cm}$ at $100 \mathrm{stems} / \mathrm{ha}$ compared with $11.0 \mathrm{~cm}$ at 200 stems $/ \mathrm{ha}$ and $7.6 \mathrm{~cm}$ at 400 stems/ha. Measurements at Tikitere also indicated fewer broken tops due to cyclone damage as tree stocking increased (Knowles \& Paton 1989). If unpruned log grade specifications tighten, which seems likely as increasing quantities are exported, then clearly the prices received for the upper unpruned logs at lower tree stockings will suffer.

\section{Discussion}

\section{Funding agroforestry}

The financial input required to develop the first few hectares of agroforestry shouldnot be any impediment to most landowners. Despite this, a recent survey (Morey 1988) found that only 6\% of Bay of Plenty farms had any agroforestry plantings.

Because of the long-term nature of agroforestry. it is important that any significantly sized project is carefully planned. Obviously the scale and timing of the conversion of open pasture to agroforestry has to be done in such a way that both capital and labour are available. Two costs are involved -one is the cost of establishment and tending. Using family labour has worked well on the Roydon Downs project, with the silviculture from 4 ha of new planting each year being done on time. Figure 5 shows that the second and largest cost, especially after the first 15 years, is the income foregone fromlivestock displaced by the trees. The landowner considering a sizable agroforestry project has several options: the project can be funded from existing resources, from a bank loan (for say the last 10 years prior to felling) or by arranging a joint venture with an investor.

A typical joint venture involves the landowner and investor sharing the final revenues depending on their relative inputs of land, labour, and other costs such as rates and silviculture. Such an arrangement is possible under the Forestry Rights Registration Act (1983). Details on joint ventures are given in Anon (1985.1991). In our analysis, we posed the question: What proportion of the fiial net revenues from the sale of trees would be required to compensate an investor who met the early costs of silviculture, grazing foregone, or both? While this is a legitimate question to ask, we emphasise that it implies a rather unconventional joint venture.

Figure 9 shows that these proportions are very dependent on the discount rate used in the calculations and on the regime/site particulars. At discount rates of $10-11 \%$, the analysis indicates that an investor meeting all silvicultural costs in the 135 and 225 regimes would require $40-50 \%$ of the final net revenue at harvest, with the landowner who has 'contributed' the income foregone from the livestock taking the remainder. At discount rates of less than $10 \%$, there is an apparent surplus which could be distributed on a basis of the ratio of inputs or claimed by eitherparty. In a situation where alandowner was able to convince an investor that a real pre-tax rate of return of $7 \%$ was acceptable, and the investor was to meet the costs of silviculture and grazing foregone, about half the net revenues would be available to the landowner in return for nil contribution.

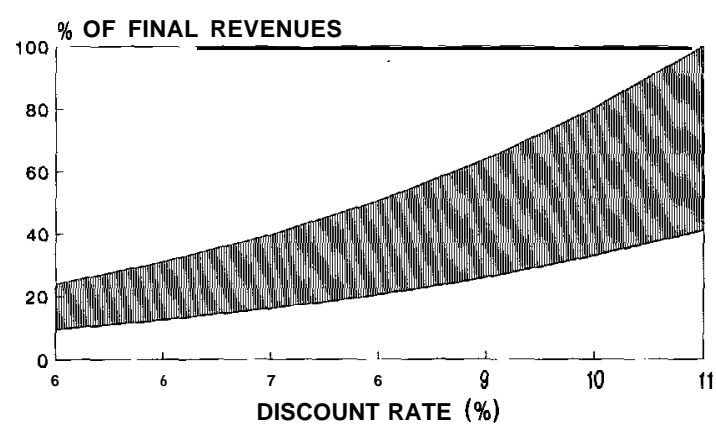

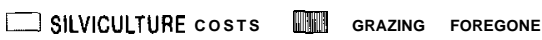

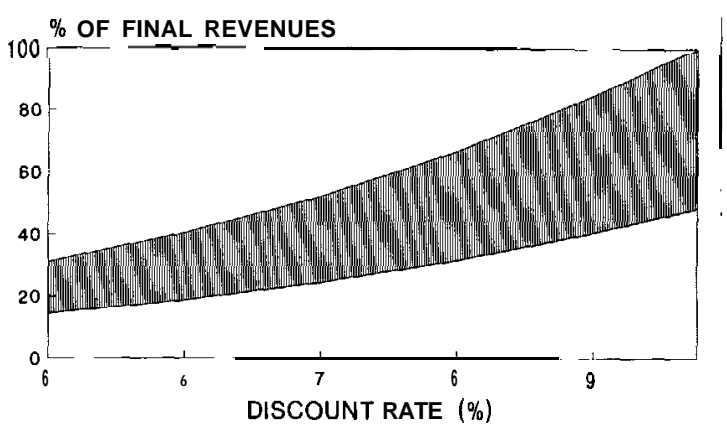

$\square$ SILVICULTURE costs $\quad$ Q

Figures 9a (135stems/ha - top) and 9b (225 stems/ha $\pi$ above) Proportion of final net revenues to be shared with an investor who meets the costs of silviculture, grazing foregone, or both. 


\section{Why has agroforestry not been more widely practised?}

The level of agroforestry planting by the private sector is low considering that over 100,000 ha of pasture are on slopes greater than $15^{\circ}$ (i.e., similar to the planted land on the Roydon Downs farm) in the Bay of Plenty region (M. Vine, pers. comm.). Given that initial plantings of 1 or 2 ha are sufficient for landowners to gain experience with agroforestry and cost very little, we conclude that lack of available funds is not the reason. Hawke \& Maclaren (1990) observed that farmers and their advisors were often unaware of the high values currently being received from the sale of trees. They concluded that agricultural organisations need to accept that agroforestry is not an 'alternative' land use but an opportunity for mos $t$ farmers. Inevitably, we will see an increase in investment in agroforestry from sources outside the traditional agricultural sector (for superannuation purposes for example). We agree with their conclusion: "Unless there is a change in attitude, the role of the farmer will be that of a spectator rather than participant".

\section{Effect of location}

Log cartage currently costs $\$ 0.14-0.18 / \mathrm{m} 3 / \mathrm{km}$. For each $\mathrm{km}$ increase (or decrease) in cartage distance, the cash flows calculated for the Roydon Downs property at normality arereduced (or increased) by $\$ 99 /$ ha (i.e., $\$ 297$ for a 3 ha felling programme).

\section{The future}

Once significant fellings start, based on the present plantings on the Roydon Downs property, planting the remaining 80 ha of hill country will be considered. For new plantings, the final crop stocking has been increased from 135 stems/ha to 225 stems/ha. Recent research results (confirmed by our observations) show that trees grown from physiologically aged cuttings produce much straighter and better formed trees in agroforestry situations than those grown from seedlings (Menzies \& Klomp 1988). Wherever possible these cuttings will be incorporated in future plantings.

\section{Conclusions}

After 20 years of experience with radiata pine based agroforestry we have come to the conclusion that the system is highly profitable and appropriate for much Bay of Plenty hill country presently in pasture. Regimes involving 13.5 and $225 \mathrm{stems} / \mathrm{ha}$ are similar in terms of economic return, but the 225 regime is likely to be superior in terms of the overall quality of $\log$ s produced.
This study indicates that cash flow constraints arc best met by varying the total area planted, and rate of conversion of pasture to trees, rather than by reducing the number of stems/ha. The system appears to be a straightforward, low cost, environmentally sustainable way of better utilising land. Planting theleastproductive third of the farm is predicted to more than double the farm surplus. Landowners should not be put off by the long-termnature of agroforestry investment. Somehow, each landowner has to break out of the current downward spiral in farming profitability. Why not start this winter and plant your first 2 hectares?

\section{ACKNOWLEDGEMENTS}

A key element in this analysis has been the completion of the agroforestry estate model. We thank Bruce Manley and Stephen Wakelin for providing output from existing estate models for comparison purposes, and Phillip Middlemiss forprogramming. This project was partially funded by the New Zealand Agroforestry Research Collaborative.

\section{REFERENCES}

Anon 1985. Guidelines for Participants in Joint Venture Forestry. Information Paper No. 1. New Zealand Forestry Council, Wellington, New Zealand.

Anon 1991. Report from Forestry Joint Venture Working Group. Ministry of Forestry, Wellington, New Zealand, 35 pp.

Brann, G.J. 1991. $\$ 40,000$ a hectare is possible. New Zealand tree grower, August 1991. p 11.

Brann, G.M. \& Brann, G.J. 1988. Farm-scale agroforestry in the Eastern Bay of Plenty. In P. Maclaren (Ed.), Agroforestry Symposium Proceedings, New Zealand Ministry of Forestry.

Forest Research Institute, Bulletin 139: 45-52.

Hawke, M.F.; Maclaren, J.P. 1990. Agroforestry - an opportunity overlooked. Proceedings of the $\mathrm{NZ}$ Grassland Association 51: 55-58.

Knowles, R.L.; Paton, V.J. 1989. Effect of Final-crop Stocking on Wind Damage at Tikitere. In A. Somerville, S. Wakelin and L. Whitehouse (Editors) Workshop on wind damage in New Zealand exotic forests. New Zealand Ministry of Forestry. Forest Research Institute, Bulletin 146: 34-37.

Menzies. M.I.; Klomp, B .K. 1988. Effects of parent age on growth and form of cuttings, and comparison with seedlings. In M.I. Menzies, J.P. Aimers and L.J. Whitehouse (Editors) Workshop on growing radiata pine from cuttings. New Zealand Ministry of Forestry. Forest Research Institute, Bulletin 135: $18-41$. 
Ministry of Agriculture and Fisheries 1990: MAF Farm Monitoring Report, North Central Region. December 1990. Ministry of Agriculture and Fisheries, Ruakura A gricultural Centre, Hamilton.

Morey, C.M. 1988: Farm Forestry in New Zealand: A 198586 Survey of Farmer Practice, intentions and opinions. In P. Maclaren (Ed.), Agroforestry Symposium Proceedings, New Zealand Ministry of Forestry, Forest Research Institute, Bulletin No. 139, pp 19-34.

Percival, N.S. and Knowles, R.L. 1988: Relationship between radiata pine and understorey pasture production. In P. Maclaren (Ed.), Agroforestry Symposium Proceedings, New Zealand Ministry of Forestry, Forest Research Institute, Bulletin No.139, pp 152-160.

Percival, N.S., Hawke. M.F., Jagush, K.T., Korte, C.J . and Gillingham, A.G. 1988 Review of Factors affecting animal performance in pine agroforestry. In P. Maclaren (ed.), A groforestry Symposium Proceedings, New Zealand Ministry of Forestry, Forest Research Institute, Bulletin No.139, pp 165-174.

\section{APPENDIX 1 : BASIC ASSUMPTIONS USED IN THE ANALYSIS}

SILVICULTURAL REGIMES, INCLUDING LABOUR REQUIREMENT

\begin{tabular}{|c|c|c|c|c|c|}
\hline \multirow[b]{2}{*}{$\begin{array}{l}\text { Stand } \\
\text { aoe (vrs) }\end{array}$} & \multirow[b]{2}{*}{ Operation } & \multicolumn{2}{|c|}{135 stems/ha Final crop } & \multicolumn{2}{|c|}{225 stems/ha Final crop } \\
\hline & & stems/ha & $\begin{array}{l}\text { Labour } \\
\text { (hrs/hal }\end{array}$ & stems/ha & $\begin{array}{l}\text { Labour } \\
\text { (hrs/ha) }\end{array}$ \\
\hline 0 & Plant & 150 & 2.5 & 300 & 5.0 \\
\hline 0 & Release spray & 150 & 1.65 & 300 & 3.3 \\
\hline 3.8 & Prune to $2.2 \mathrm{~m}$ & 140 & 5 & 250 & 8.3 \\
\hline 4.8 & Prune to $3.6 \mathrm{~m}$ & 140 & 5 & 225 & 7.5 \\
\hline 5.9 & Prune to $5.2 \mathrm{~m}$ & 135 & 7 & 225 & 10.5 \\
\hline 7.2 & Prune to $6.3 \mathrm{~m}$ & 75 & 7 & 135 & 10.5 \\
\hline 8.0 & Prune remainder to $6.3 \mathrm{~m}$ & 60 & 4 & 90 & 6.0 \\
\hline Various & Thin to waste & 15 & 0.5 & 75 & 2.5 \\
\hline
\end{tabular}

B.

PRUNED LOG PRICES, AT THE FARM GATE $\$ \mathbf{M}^{3}$

\begin{tabular}{lcc}
\hline Stand age $(\mathrm{yrs})$ & 135 stems/ha Final crop & 225 stems/ha Final crop \\
\hline 22 & 119.25 & 103.15 \\
27 & 139.90 & 120.65 \\
32 & 155.65 & 133.95 \\
\hline
\end{tabular}

C. CALCULATION OF UNPRUNED LOG PRICES AT FARM GATE (STAND AGES 22-32) $\mathbf{\$} / \mathbf{M}^{\prime}$

\begin{tabular}{lccccc}
\hline Log grade & FOB & Wharfage & Cartage & Commission & Farm gate price \\
\hline 'A' Japan & 110 & 13 & 8.50 & 11.00 & 77.50 \\
'K' Korea & 90 & 13 & 8.50 & 9.00 & 59.50 \\
Pulp - Korea/Japan & 50 & 13 & 8.50 & 5.00 & 23.50 \\
\hline
\end{tabular}

D. COSTS FOR LOGGING, LOADING, ROADING AND LOGGING SUPERVISION \$/M (APPLIES TO ALL LOG GRADES)

\begin{tabular}{lcc}
\hline Stand age (vrs) & 135 stems/ha Final crop & 225 stems/ha Final crop \\
\hline 22 & 20.20 & 20.80 \\
27 & 18.50 & 18.50 \\
32 & 17.00 & 17.00 \\
\hline
\end{tabular}


E. VOLUMES BY LOG GRADE (M'/HA)

\begin{tabular}{|c|c|c|c|c|c|}
\hline Stand age (yrs) & Pruned & A & $\mathrm{K}$ & Pulp & Total \\
\hline \multicolumn{6}{|c|}{135 stems/ha Final crop } \\
\hline 22 & 124 & 21 & 116 & 56 & 319 \\
\hline 27 & 156 & 41 & 161 & 90 & 450 \\
\hline 32 & 162 & 34 & 196 & 146 & 560 \\
\hline \multicolumn{6}{|c|}{225 stems/ha Final croo } \\
\hline 22 & 146 & 35 & 150 & 96 & 425 \\
\hline 27 & 191 & 94 & 169 & 109 & 563 \\
\hline 32 & 220 & 126 & 241 & 128 & 715 \\
\hline
\end{tabular}

F. OTHER COSTS

Labour cost (for contract silviculture) (see Part A for hours involved)

Supervision charge (for contract silviculture)

Regrassing charge

Materials cost at planting

Plants and herbicide $\quad 150$ stems/ha

300 stems/ha

Supervision charge included in logging cost

Cartage cost $\$ 0.17 / \mathrm{m}^{3} / \mathrm{km} \times 50 \mathrm{~km}$

$\$ 20 / \mathrm{hr}$

$25 \%$ of contract costs

$\$ 450 /$ ha

$\$ 65$

$\$ 170$

$\$ 3.50 / \mathrm{m}^{3}$

$\$ 8.50 / \mathrm{m}^{3}$ 